\title{
MEDIA COMMUNICATION AND CULTURAL HYBRIDIZATION OF DIGITAL SOCIETY
}

\author{
Mario Plenković1, Daria Mustić ${ }^{2}$ \\ Faculty of Graphic Arts, University of Zagreb, Zagreb, Croatia \& Alma Mater Europaea - ECM \& University of Maribor, \\ Faculty of Electrical Engineering and Computer Science, Institute of Media Communications, Maribor, Slovenia ${ }^{1}$; Faculty of \\ Graphic Arts, University of Zagreb, Zagreb, Croatia ${ }^{2}$
}

\begin{abstract}
The paper is analyzing basic operative terms of visual communication in contemporary digital media environment, which determinates analytical units of media communication and the new culture of communicating and message dissemination. Theory discussion is conducted by diachronic and synchrony analysis of elements of visual communication in digital environment and theory of public action. The main goal is to establish new communicative paradigm of media communication which includes the evaluation of digital skills, media literacy and the characteristics of the new hybrid digital society. Authors observe modern media communication and visual digitalization, not only in technical sense of transmission and adjustment of analog signal into digital signal, but also, simultaneous development of digital culture and adaptation of media content, media production and distribution of content to the new web environment (Web 2.0, Web 3.0, Web 4.0 and theoretical possibilities of so called Web 5.0) deriving the new contexts of social power.
\end{abstract}

Keywords

communication science, digital society, media, culture, visual communication, public

\section{Introduction}

Digital transformation affects work, production processes, planning, information management, their archiving, education, formal and informal learning, therefore changing the daily lives of individuals, families, business organizations, countries. It is inevitable, indispensable and self-evident. The digital economy is developing rapidly worldwide. Digital transformation cannot be reduced only to the replacement of production technology, it also includes the transformation of people creators and users of digital media messages, and thus enables the creation of a hybrid digital society. The possibilities of digitalization are great today, and the possibility of new forms of work and communication is even greater. The process of digital transformation of society is extremely complex, so the EU has set up the Digital Europe program with a total budget of $€ 9.2$ billion to shape and support the digital transformation of European societies and economies. The five priority areas within the Digital Europe program are supercomputing, artificial intelligence, cybersecurity and trust, advanced digital skills, and ensuring the widespread use of digital technologies throughout the economy and society /1/. All five areas, which cover the scope of technology to the human, social component, are extremely 
important for the further development of digital media communication.

Visual media communications, under the strong influence of information and communication technologies (ICT), are adapting to new technologies but at the same time they put individuals in the face of the challenges of disinformation, populism, social irresponsibility, media manipulation, image manipulation, and consequently the challenges of generating and (un)intentionally sharing fake news - information quality today is challenged by the lack of traditional gatekeepers. That is just one of the many reasons why digital transformation is generating a strong debate, sometimes discordance, among policy-makers, economists, scientists and industry leaders about its societal impact. But, despite the disagreements, we can say that the new historical communication era is more and more determined by digital technologies, information processes, visual communication, interactive communication, Web 4.0 technologies and spreading of digital citizens networks.

Digitization is also lowering the costs of storing, sharing, and analyzing dana and by that is giving to mankind the potential collaboration with the possibilities of storing huge amount of data. That leads to maximizing limited human communication capacities. Inspite of these great possibilities that digitization is providing, according to Eurostat, there is a big digital divide between northern and western EU Member States on one hand and southern and eastern EU Member States on the other. /2/

\section{Theoretical and methodological concept}

The basic goal of this paper is to explore and to analyze new communication knowledge and accomplishments, which can be used in the process of holistic analysis of media and visual communication, visual culture and visual literacy in the context of digital transformation in Croatian and international regions. The purpose of the paper is to determine, categorize and create terminology for basic operative communication concepts, which are used in the new contemporary communication trends enabled by new technologies in the new area of development and improvement of graphic communication in completely digitalized media environment. The paper is longitudal study based on the concept of previous published study /3/, complemented by theoretical reflections based on new technologies, social consequences and changes in cultural patterns, which were also reflected in the behavior of media audiences. Under the influence of different behaviour of media audiences and the different consumption habits of media content there is a change in the dynamics of communication and the dynamics of social changes - the result is hybridization of digital society.

\section{Structure of visual communication system}

Visual communication is logical, gnostically, ethical, esthetical and metaphysical communication ponderation of creating and intermediating messages, in which man (creator) becomes "homo ludens" (playful man in science and art) on his way into modern "homo faber" "man who works with digital tools". Visual communication is a complex and continued communication and interactive process in which the author (creator), as a sender of the message; is forming visual communication, because he wants the recipient to believe that the message has the socially accepted meaning. Visual communication, from the communication science aspect, is the aimed «individual or social consensual validity», which is accepted and approved by individuals, social groups (culture, art, science, sport, education, and economy), church and religious groups, political parties, state and social institutions and wide citizen public. / $\mathbf{3} /$

The concept of social validation is old as society itself, but it found new forms in digital social networks, which all implement some way of visual sign of social approval (like sign, heart symbol, thumbs up for example). In highly digitalized society, social validation gives the feeling of social approval or some kind of social punishment - the senders of the visual messages (in ads, videos, web pages, personal or business pages ) are suggesting to the recipient of the visual message possible «social or individual award», which will be gain by taking intermediated message and also possible, negative "individual or social consequences", 
which we can expect if we refuse to take intermediated message.

One of the biggest achievements of human mind is written communication, which enabled coordination of complex human activities and also the creation of cultural identity without limits of time - with written communication mankind created the connection between past, present and future - the basis for cultural identity was created. Invention of writing signs has stimulated civilization and cultural development more than any other doing in a mankind history /4/. In the oldest societies literacy was, in communication sense, an expression of prominent and significant social role, always in correlation with religion and ruling. Today, mankind has reached global communication and the world is, now for decades, transformed into "a global village". Creator (author) of the mediated message has no longer possibilities of influencing on communication process and the path and digitalized distribution of his thought expression delivered as media content and he also loses the control of the message and that is the certain destiny of all messages in contemporary digital media environment.

Philosophy of creating visual messages is contained in cognitive and esthetical knowledge in the process of creating and intermediation of visual communications.

Communication with visual signals has advantages over other means of communication since the visual message reaches the recipient simultaneously, at high speed. Shapes, colors, movement and depth, as components of the visual communication of messages are unlimited.

The theory of aesthetics says that aesthetics is one of the most important factors of the visual communications. These are unattainable qualities that cannot be easily defined, but we are aware that very they act powerfully on us. This is an important issue that is explored in visual communications. It suggests that, because of the nonverbal nature of aesthetics, what can be written and interpreted is only speculation about the nature of visual aesthetics and, therefore, cannot be visual aesthetics itself. /5/ Aesthetic aspects of visual communication are visible, structural and configurational in nature, implicit in comprehension, holistic in conveying meaning (cannot be fully translated in dissected and discursive form) and cognitive in a generative sense, based on a unique type of visual logic. Questions of visual aesthetics have been studied throughout history within the framework of psychology, art, and science. Of all the disciplines, visual arts provide the most complete and most appreciated explanation of visual understanding. But today everything a number of disciplines and sciences can provide factual evidence to define how aesthetic qualities play a fundamental role in human communication./5/ 


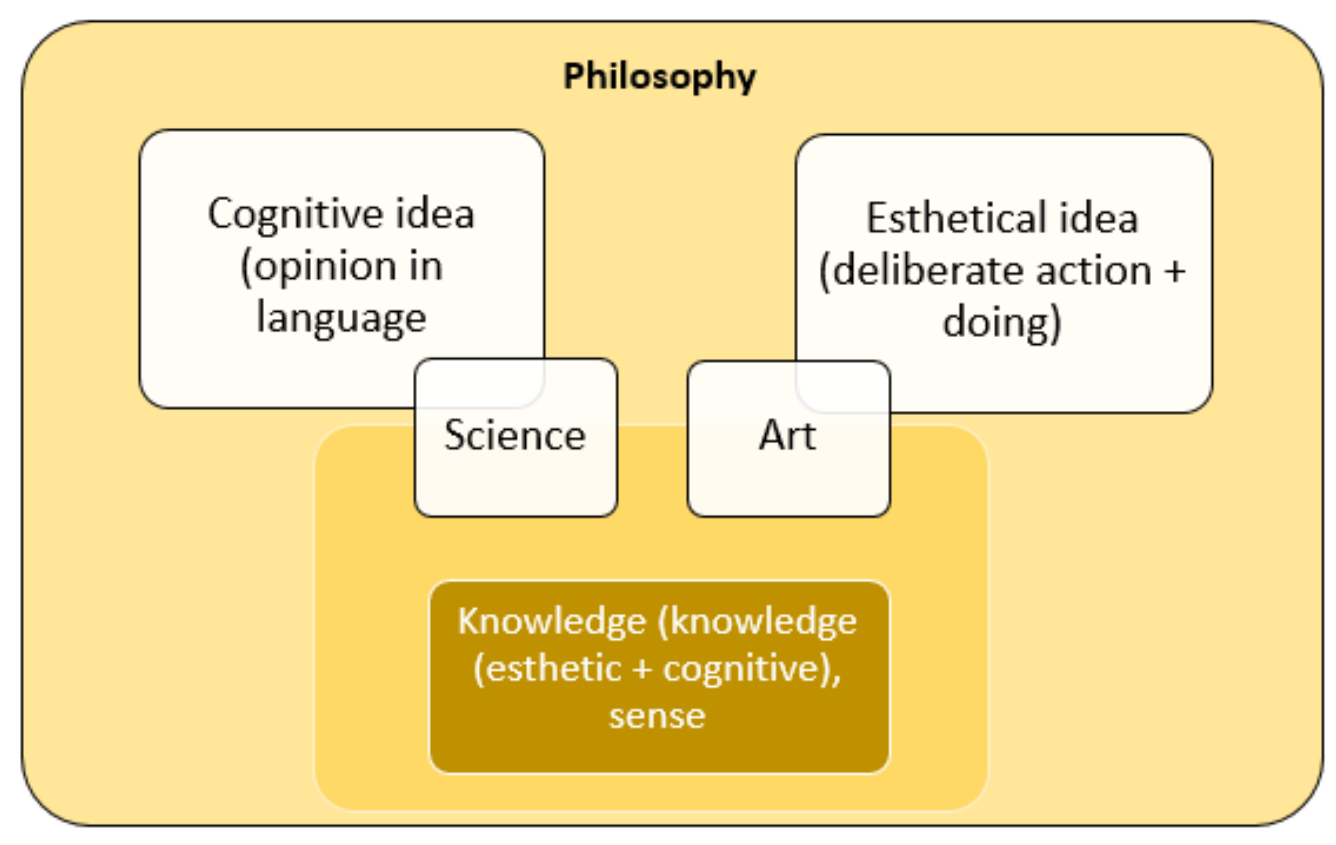

Figure 1. Relation between philosophy, science and art - adjusted according to /3/

F. Bacon /6/ said that on the way of human cognitive holistic development, there are four constant threatening mistakes, and those are: "idol tribus" (all that man can see is only a view from limited perspective of "homo sapiens", who is not capable of understanding the whole universum); ,idol specus“ (besides general anthropomorphic limitations man is also limited by his individual constitution of looking at the world and life); "idol fori“ (man is finally limited by uncritical fashion, which arises from common uncritical knowledge); and "idol theatri“ (man knowledge is limited by communication possibilities, that is dogmatic learning which are imposed by force).

In the tradition of semiotics theory by de Saussure the sign relation is dyadic, consisting only of a form of the sign (the signifier) and its meaning (the signified). Saussure saw this relation as being essentially arbitrary, motivated only by social convention.
Peirce attempted to set out a truly general theory of signs. For Peirce, the sign had both a concrete and an abstract nature. He defines a sign as a triadic relation as something that stands for something else, to someone in partial capacity.

In every communication process basic elements of communication are consisted: sender (creator) of the message, process of coding the message, communication channel, possible trammels in communication channel, process of decoding, message recipient and possibility of feedback information. On the same principles and according to semiotic theory, Ralf Lankau /7/ operates visual system of graphic communication which includes, besides text, images and info graphics, two basic communication-graphic terms "grams" and "graphic", which with their terminology roots, determine all basic visual and graphic communication terms: 


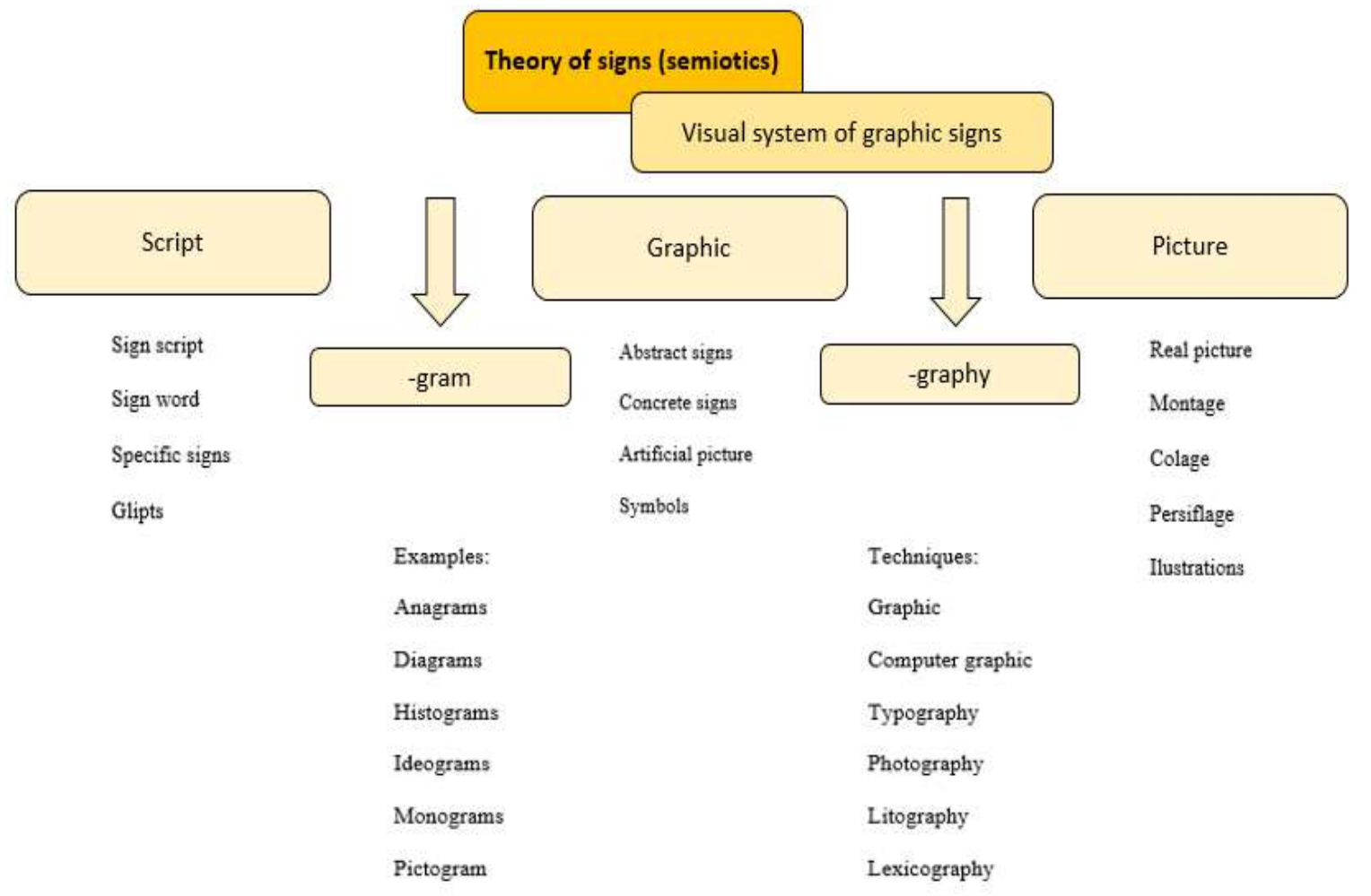

Figure 2. adjusted according to /3/

4 Communication terms in research of communication in digitalized media and cultural environment

For understanding the structure of communication process in context of digitalized media and cultural environment, it is necessary to define basic operative communication terms which are used in scientific and phraseology standard communication and graphic media discourse. The basic terms in the analysis of visual communication system are information, communication, media, communication science, visual communication and public.

Without determination of basic terms and secondary communication terms, it is impossible to start any serious communication discussion and research analysis of communication in the digitalized media and cultural environment.

\subsection{Terminology}

Analysis of terminology is based on the research by Plenković, Tomažič and Kučiš /3/ and supplemented by new concepts without which today, only a decade later, from the original text, it is no longer possible to explore media and visual communication in the new context of an already formed digital societies and emerging digital societies.

Etymologically, (in)formation means to put in form (in forman), to be in a essence. As cognition, of course, information is connected with a category of power, because the right of the beginning knowledge is always some form of human power above what is known. In „Dictionary of Foreign Words" written by V. Anić i I. Goldštein, information is determined /8/ as a notice about facts, report on something, element of knowledge, elementary notice which can be transmitted and formed, thanks to code and device. Information is consumed through a communicative process which begins by accessing the information from a source. In information science, search engines are considered information retrieving systems - IR systems and the process of retrieving information is considered an information search process (ISP). The most important IR system and the most dominant sources of information today is the commercial search engine. A great number of the population use these search engines to 
gather all forms of information. The search engine represents a gateway, a form of control owned and operated by private, for profit businesses. While they do not own the content, they have complete control over the view of that content. These information sources exist in a larger socio-economic framework which impacts the construction and distribution of information. /2/

Communication is information, which transforms from status per se to utilization value; it becomes value to other people too. To communicate means to give and to receive information, to be in touch; to serve, to maintain, to establish, to make communication. Communication science is a science which deals with structure of communication processes and systems (communication + logos). Communication process is defined by its origin, historical, tehnological, cultural and social frames. /11/

Visual (adjective) relates to seeing or sight. Visual identity is one of the ways of presenting business enterprise to the public. The corporate identity is typically visualized by branding and with the use of trademarks or a group of art visual (style or symbolic) characteristics, which reflects communication specifics of a firm or a product. Visual media is an instrument for transmitting messages intended for sight (paper, TV, film, www pages). Visualization is an ability to present or imagine something in images (info graphic).

Media is a presumption of so called materialization of information. Without transposing information in some communication media (speech, sight channel, electromagnetic waves, letter, book, web, info graphic...), it stays invisible and inaudible to all people, except to the author (creator). Mediation is an intermediation of a third party in a conflict between two sides. Medius is something around everything gathers, center, which is in the middle (lat. Medianus). Mediator is someone who intermediates, someone who is between sender and the receiver of the information. Media (adjective) is the one who belongs to the media (media man). Bazalgette /12/ argues that media literacy includes skills that enable individual to critically deconstruct the media and prevent manipulative effect. According to Garcia Ruiz et all. /13/ media literate person, a modern "prosumer « knows how to arrange the necessary resources for generating creative and innovative content; he/she is a reviewer, of the content he or she receives, as well as that which s/he creates, with a critical, thoughtful and pluralistic eye; he or she has to be an observer of the message's production and emission processes, as well as its impact, taking into account the possible audiences; he/she should be a selector of the content and a unifier of the criteria for quality, equality, inclusion, and the maximal diffusion of the message, a manipulator of the technological tools that are adapted to the new communications media, as well as an identifier of stereotypes, bad practices, abuse and lack of veracity of some messages that are distributed through communication media and social networks, a booster of the communication and interaction between emitters and receptors, the organizer of the resources that are required for the production of creative, critical and responsible content...

Publicity (German Öffetlichkeit, French publicity) is referring to what is public (lat. Publicus). Public (1) is a group of all individuals who are pointing theirs attention to questions of public interest, (2) sphere of communicating between audience members (gathering, associations, communication meanings) and (3) organization principle of acting of institutions and institution bodies, which are established with aim of taking care of common and public interest $/ \mathbf{1 4} /$. Public opinion is, according to J. Dewey, judgment formed by the ones who are making public, and it refers to public affairs /3/. W. Lippman in wider definition claims that public opinion consists of images in our heads about human beings, images about us, about the others, their needs, goals and relationships /15/.

The word culture is derived from Latin word cultivare, which means to take care, to honor. Culture is a universal good which should be explained to every individual and publics /16/. Visual culture is a totality of material and spirit goods, ethical and social values, created by a 
mankind /3/. E-visual culture is an expression which is used in visual culture and in reaching wanted goals in visual and cultural media policies /3/. Image is a visual appearance or impression in public, behavior towards audience, public and society in general $/ 3 /$.

Digitalization is transmission of visual messages in digital graphic form /3/. Internet and digital media are observed in context of development of culture of visual communication in all segments of cultural doings (graphic communication, music, visual culture, design, media culture, film and civil living) /3/. Digital self-entities are charged with symbolic meaning and are evolving dynamically - they emerse themselves in social environments with an ever-expanding compendium of symbolic tools at their disposal to present their identities to others $/ \mathbf{1 0} /$.

Strategy is observed as a long term way of reaching communication goals in visual communication in public and in general public movements $/ 3 /$.

\subsection{Media and visual message}

Process of using and visual messages is determinated, according to R.Lankau $(2007,78)$, by using media in the process of intermediation of visual communication (coding, forming and channel). But, the world wide web today is a participatory community where both users and information sources co-create, share and modify content. /11/ 


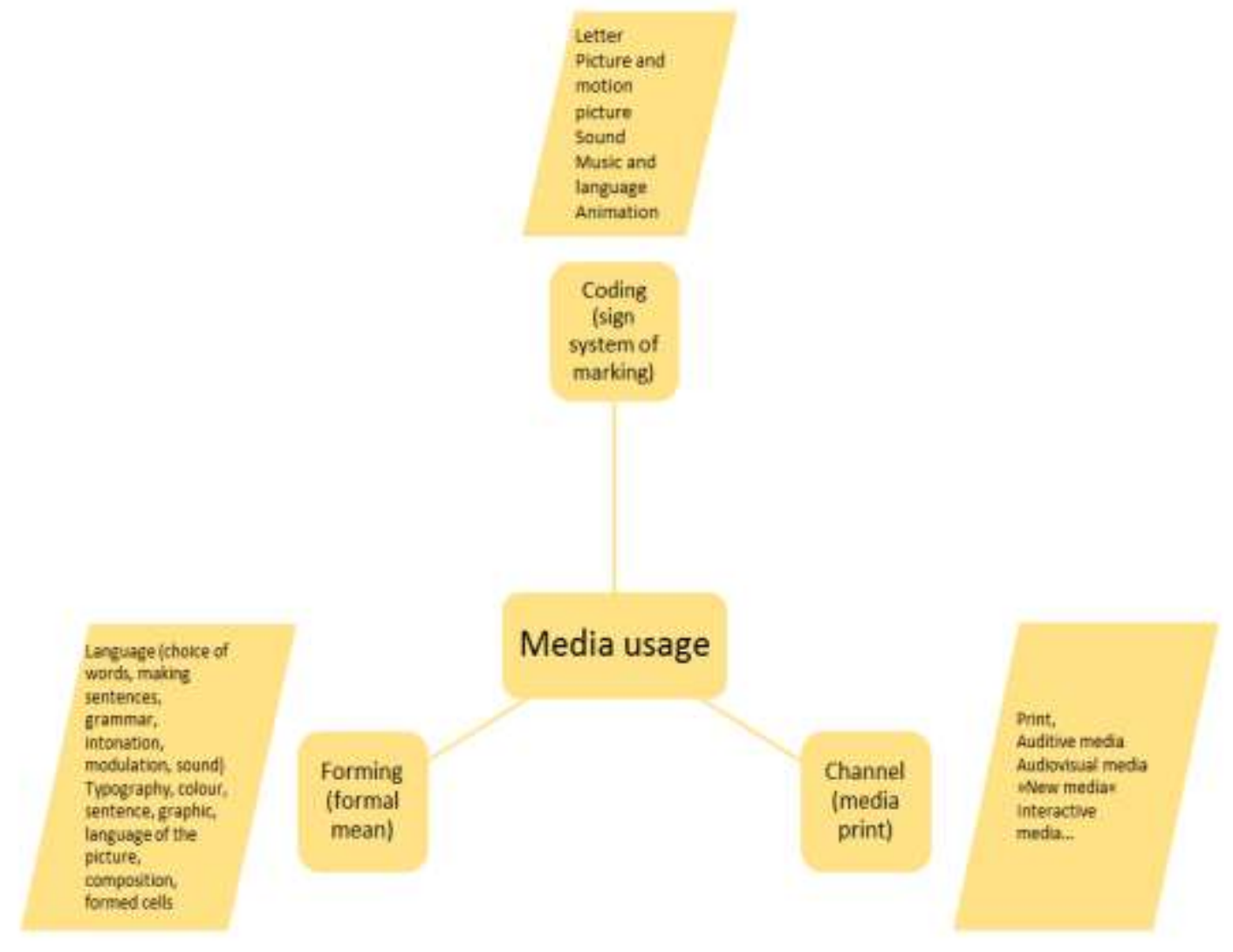

Figure 3. adjusted according to /3/

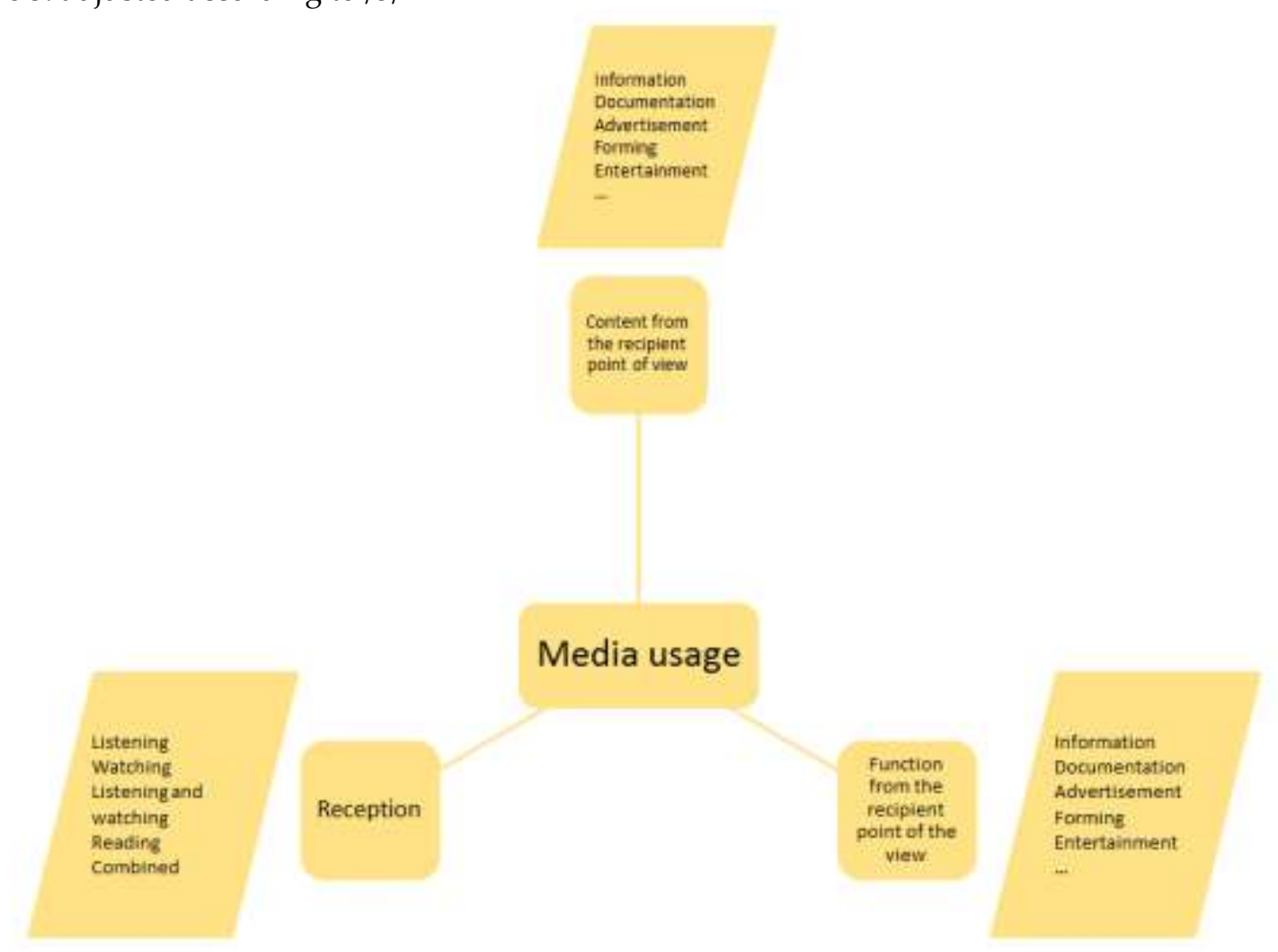

Figure 4. adjusted according to /3/ 


\section{Concluding comments}

The obtained analyisis of communication terms and conducted communication analysis of the essence of visual and media communication including media communication culture in a new new paradigmatic contribution in theoretical analysis of communication system sin the new inclusive digitalized society. The holistic approach to media communication as an cultural phenomena is is a professional and social preoccupation of every communication scientist, graphic and media designer, creator and distributor of visual messages, marketing and designer agencies, creative media and education institutions, advertisement and propaganda institutions, economy and parties' subjects, civil society and government and nongovernment institutions.

To understand communication essence and the core of creating visual communication in the technological and social environment, it was necessary to redefine and broaden basic operative terms for scientific research and praxeological creative determination of the phenomenology of visual communication.

\section{Notes}

/1/ https://ec.europa.eu/digital-singlemarket/en/europe-investing-digital-digitaleurope-programme (28.07.2020.)

/2/ Plenković, M. i Mustić, D. (2019). Relationship between users age and visual patterns in digital media. Informatologia, 52 (3-4), 164-172. https://doi.org/10.32914/i.52.3-4.4

/3/ Plenković M., Tomažič, T., Kučiš, V. (2010). Holistic Strategy for Public Action through Visual Digitalization in the Convergent Environment,
Observatorio (OBS*) Journal, vol.4 - n² (2010), 197-210 1646-5954/ERC123483/2010 197

14/ Vreg, France, (1988), Humana komunikologija, Hrvatsko komunikološko društvo \& Nonacom, Zagreb.

/5/ Kenney K., Moriarty S., Barbatsis G., Smith K. (2005.). Handbook Of Visual Communication. Theory, Methods, And Media, Lawrence Erlbaum Associates, Inc., Mahwah, New Jersey

/6/ Plenković, Mario, and Plenković, Juraj, (1999), Kvalitativna holistička klasifikacija ljudskog znanja i znanosti, in: Informatol.32, 1999,1-2, 1136 (28).

/7/ Lankau, Ralf, (2007), Lehrbuch Medingestaltung, Grundlagen der kommunikation und Visualisierung, Dpunkt Vrlag GmbH, Haidelberg.

/8/ Anić, Vladimir, and Goldstein, Ivo, (2002), Riječnik stranih riječi, Drugo izdanje, Novi Liber, Zagreb.

19/ Taylor, A. R. (2014). Postmodernist and consumerist influences on information consumption. Kybernetes, 43(6), 924-934.

/10/ Doster, L. (2013). Millennial teens design and redesign themselves in online social networks. Journal of Consumer Behaviour, 12: 267-279.

/11/ Plenković, M., Mustić D. (2016) The new paradigm of participatory communication as a result of participatory culture of digital media. Media, culture and public relations [Internet]. [pristupljeno 02.07.2020.];7(2):143-149. Dostupno na: https://hrcak.srce.hr/176502

/12/ Bazalgette, C. (1997). An agenda for the second phase of media literacy development. In Media literacy in the information age. ed. By Kubey, R., New Brunswick, NJ: Transaction

/13/ Garcia-Ruiz, R., Ramirez-Garcia, A., RodriguezRosell, M.M. (2014). Media Literacy Education for a New Prosumer Citizenship. Comunicar, n. 43, v. XXII, 15-23.

/14/ Prpić, Ivan, Puhovski, Žarko, Uzelac, Maja, (1990), Leksikon temeljnih pojmova politike, Školska knjiga, Zagreb.

/15/ Plenković, Mario, (2001), Holistička analiza odnosa s javnostima (javnošću), in: Informatol. 34, 2001., 1-2, 1-165. 


\title{
MEDIJSKA KOMUNIKACIJA I KULTURNA HIBRIDIZACIJA DIGITALNOG DRUŠTVA
}

\author{
Mario Plenković, Daria Mustić \\ Grafički fakultet, Sveučilište u Zagrebu, Zagreb, Hrvatska \& Alma Mater Europaea - ECM E Univerza v Mariboru, \\ Fakulteta za elektrotehniko, računalništvo in informatiko, Inštitut za medijske komunikacije, Maribor, Slovenija ${ }^{1}$; Grafički \\ fakultet, Sveučilište u Zagrebu, Zagreb, Hrvatska
}

\section{Sažetak}

$\mathrm{U}$ radu se analiziraju osnovni operativni pojmovi vizualne komunikacije $\mathrm{u}$ suvremenom digitalnom medijskom okruženju, što određuje analitičke jedinice medijske komunikacije i novu kulturu komuniciranja i širenja poruka. Teorijska rasprava provodi se dijakronijskom i sinkronom analizom elemenata vizualne komunikacije $\mathrm{u}$ digitalnom okruženju i teorijom javnog djelovanja. Glavni je cilj uspostaviti novu komunikacijsku paradigmu medijske komunikacije koja uključuje ocjenu digitalnih vještina, medijske pismenosti i karakteristika novog hibridnog digitalnog društva. Autori promatraju modernu medijsku komunikaciju i vizualnu digitalizaciju, ne samo u tehničkom smislu prijenosa i prilagodbe analognog signala u digitalni signal, već i istodobnog razvoja digitalne kulture i prilagodbe medijskog sadržaja, medijske produkcije i distribucije sadržaja novom web okruženju (Web 2.0, Web 3.0, Web 4.0 i teoretske mogućnosti tzv. Web 5.0) na kojima se temelje novi izvori društvene moći.

\section{Ključne riječi}

komunikologija, digitalno društvo, mediji, kultura, vizualna komunikacija, javnost 